\title{
ВЕРБАЛІЗАЦІЯ ОПОЗИЦЙНИХ КОМПОНЕНТІВ КОНЦЕПТУ ЗЕМЛЯ (НА МАТЕРІАЛІ УКРАЇНСЬКОГО ПОЕТИЧНОГО ДИСКУРСУ ДРУГОЇ ПОЛОВИНИ ХХ СТОЛІТТЯ)
}

\begin{abstract}
Огар А. О. Вербалізація опозиційних компонентів концепту земля (на матеріалі українського поетичного дискурсу другої половини ХХ століття).

У статті представлено особливості мовного втілення та семантичного наповнення тих компонентів концепту земля, які формують бінарні протиставлення. Одинадцять пар семантичних опозицій ілюструють дуальну природу концепту, його суперечливість.

Ключові слова: концепт, вербалізація концепту, компонент концепту.

Огар А. О. Вербализация оппозицийних компонентов концепта земля (на материале украинского поэтического дискурса второй половини ХХ столетия).

В статье представлено особености языковой репрезентации та семантического наполнения тех компонентов концепта земля, которые формируют бинарные протиставления. Одиннадцять пар семантических оппозиций иллюструют дуальную природу концепта, его противоречивость.

Ключевые слова: концепт, вербализация концепта, компонент концепта.

Ogar A. O. Verbalization of opposition components concept earth (on material Ukrainian poetic discourse of the second half of XX of century).

In the article the features of linguistic statement and semantic filling of those components of concept earth are presented, which form the binary contrasting. Eleven pair of semantic oppositions illustrate dual nature of concept, his contradiction.
\end{abstract}

Key words: concept, verbalization of concept, component of concept.

Чільне місце в сучасній мовознавчій науці посів когнітивний напрям, що розглядає функціонування мови як різновид когнітивної діяльності, а когнітивні механізми та структури свідомості досліджує через мовні явища. Основне поняття цієї науки - концепт - потрактовують по-різному: концепт - одиниця ментальних і психічних ресурсів свідомості, тих інформаційних структур, що відображають знання та досвід [3, с. 90]; це згусток культури у свідомості людини, те, у вигляді чого культура входить у ментальний світ людини, і те, через що людина сама входить у культуру [9, с. 42]. Одні зі складників концепту (компоненти, концептуальні ознаки, тобто ті ознаки об'єктивного чи суб'єктивного світу, що диференційовано відображені у свідомості [5, с. 60]) формують його ядро (основні поняття), інші - периферію (те, що вносить культура, традиції, досвід) [5, с. 62].

Основні принципи впорядкування концептів - протиставлення й бінарність [6, с. 18]. Бінарна логіка та ієрархічне розчленування утворюють класифікаційну сітку, що не тільки упорядковує концептуарій, але й розкриває глибинні елементи смислу його одиниць через зіставлення. Бінарноопозиційний принцип реалізований і в самих концептах: їхня структура передбачаэ ознаки, протилежні за суттю. Антонімічні зв'язки, у які вступають компоненти концепту, свідчать про дуалістичну його природу, поєднання в одному контрастних елементів.

Одне з таких складних суперечливих ментальних утворень - концепт земля - посідає особливе місце в концептуальному просторі як один 3 тих 
центрів, що творять ментальний портрет народу [4, с. 22]. I. Франко зазначає, що тема землі викликала з'яву творів першорядного значення, а це найкращий доказ того, що ця тема жива та пекуча, що вона порушує ряд глибинних суспільних і загальнолюдських інтересів $[10$, с. 176]. Цей концепт ідентифікують як основний, або ключовий, що зумовлено широтою його презентації у фразео- та пареміологічному фондах, фольклорі, художній літературі [7, с. 111]. Вагомість концепту зумовила 3'яву в українському мовознавстві присвячених йому праць $[4 ; 8 ; 11]$.

Мета статті - виявити і проаналізувати мовне втілення та семантичне навантаження бінарних протиставлень концепту земля в поетичному дискурсі другої половини ХХ століття.

Концепту земля притаманна розгалужена парадигма семантичних опозицій. Його багатовимірність та об'ємність сприяє поліінформативності та поліаспектності охоплених ним дихотомічних пар, які опредмечують приховані грані концептуального змісту.

У структурі концепту земля виділено 11 бінарних протиставлень.

Батьківщина-чужина. Ця дихотомія грунтується на розвитку семантики народнопісенного слова, адже саме в українській народній пісні моя сторона протиставлена далекій чужій стороні [2, с. 37]. В обстежуваних поетичних текстах рідна земля постає єдиною та рідною (О земле рідна, Украӥно! У світі іншої-нема (Д. Білоус), обкраденою, але сильною (Ти вже не згинеш, ти двожилава, земля, рабована віками, $і$ не скарать тебе душителям сибірами і соловками (В. Стус), родючою, але сповненою мук i страждань (Чорноземна моя стороно, Мозоляста долоне, Де твоє океанне зерно, Наче злото червоне? (Д. Павличко); I хай щзо хочуть - $i$ земля стражденна ия, $i$ все, $i$ всі, - я вичерпавсь до дна (Л. Костенко), дорогою та коханою (Я квиснути не стану, Хоч як не буде боляче мені, - За нашу землю, дорогу й кохану, Я рад прийнять на себе всі жалі (В. Симоненко), неповторною, святою, євшанною та тополиною (Земля свщанна, тополина, той неповторний рідний край, щуо з ним зв'язала пуповина, - дитячих літ ясний розмай ... Свята земля, ти вічно з нами... (Д. Білоус). Поети засвідчують свою любов до отчої землі, єдність 3 нею (Земле рідна! Мозок мій світліє, I душа ніжнішою стає, Як твої сподіванки і мріі У життя вливаються моє. Я живу тобою $і$ для тебе, Вийшов з тебе, в тебе перейду, Під твоїм високочолим небом Гартував я душу молоду (В. Симоненко), ідеалізують їі (Прилітають до нашого поля із далеких краӥв журавлі. Розцввітають і квіти, і доля на мойй украӥнській землі (М. Сингаївський).

У поезії лексеми-вербалізатори рідного краю семантично протиставлені негативно забарвленим вербалізаторам чужини: I згорілі модрини кричали, тонко олень писався в імлі, $і$ зійшлися кінці і начала на оцій чужниецькій землі (В. Стус); Ще видиться: далекий край чужнй, в 
ньому жінка, здумана зигзиия... (В. Стус); Він [князь] сподівався, щзо земля ворожа Відчиниться $і$ степ його поглине (Д. Павличко).

Рай-пекло. Поети другої половини ХХ століття трактують усе суще, зокрема землю, як сукупність суперечностей. Так, залежно від обставин земля може бути місцем мук, страждань, пекельних трудів або місцем абсолютного щастя, раєм. Це реальність продиктувала поетам рядки, що відтворюють важке, сповнене терпінь, горя і болю існування. За релігійними віруваннями, таке чекало грішну людину після смерті в пеклі. Актуалізація образу землі поряд з вербалізаторами пекла та його атрибутів (муки, горе, гріх), безперечно, ототожнює їх: Місяцьь тане ув імлі, всюди пекло на землі... (П. Мовчан); ... Одмучилась. Одгорювала на цій неправедній землі (Л. Костенко); Зі стін скобочених виснуть патрони Без лампочок, наче старі мікрофони, У них я на всесвіт гукаю: «Ал-ло! Ви чуєте біль мій із пекла земного?» (П. Воронько); Чи не тому крізь пекло ми йдемо На цій землі і вогняне клеймо Несем на чолах... (Д .Павличко).

Рай на землі, за твердженням поетів, - це щасливе життя, можливе, але концептуалізоване як марево, як щось нездійсненне і недосяжне: Здавалось, розійтись туманам, $i$ воссіяе крізь туман - ота земля обітована, котрої на землі нема (І. Жиленко); Той хлопчик, листа прочитавии: - Жени! - скричав візнику $i$ - в дорогу, в дорогу - до того сліпучого щастя земного, щуо навіть безсмертя - ніщуо перед ним (I. Жиленко); I. може, тому я творю добро I мучу Землю, світ і все на світв Сдиним запитанням: щцстя, де ти? (М. Вінграновський).

Сакральність-профанність. Віковічна залежність людини від землі та іiі дарів стала основою давніх вірувань у те, що земля - жива істота, божество [1, с. 48, 71]. У структурі концепту це відображають ті складники, що акцентують трансцендентну природу землі. Концептуальна ознака «сакральність» вербалізована насамперед прикметником свята або іншими спільнокореневими словами: Поховали старенького діда, закопали у землю святу (В. Симоненко); То був насправді хлібороб - Свята земля його любила (М. Руденко); А я, статечність розпатлавии прудко, На глину йду, як на святий поріг... (І. Драч); Ще видиться: далекий край чужий, в ньому жінка, здумана зигзиця, шепоче спрагло: Боже, хай святиться, о най святиться край далекий мій (В. Стус). Часом сакральність прямо не номінується, а виражена усім смислом поетичного фрагмента, що ословлює землю як вище начало (Дарма, щзо трохи вже й сивенькі - то місяцьь скроням догодив. Зійшло до нас благословення землі, i неба, $і$ води (І. Жиленко), вищу істоту, що окрилює людину (Пахне хлібом маля, Що любов його народила. Пахне хлібом земля, Що дала мені сонце й крила (Д. Павличко).

Натомість прафанне трактування землі як символу буденності, сірості, зневіри, ницості, марності та суєтності зумовили релігійні настанови. За ними, земля асоціюється з низьким, людським, матеріальним 
на противагу високому, ідеальному та божественному. Це підтверджують такі рядки: Надто мало землі для духу. Надто для душі, звалошеної тісно на планеті, де жити - горбитися (В.Стус); Тут [на землі] стільки злої суєти ми нагромадили круг себе, щзо вже розведено мости між тротуарами i небом (I. Жиленко); Мільярди вір зариті в чорнозем, Мільярди щзасть розвіяні у прах (В. Симоненко); Одмучилась. Одгорювала на цій неправедній землі (Л. Костенко).

Дарувальниця-забирателька. Обстежувана поезія ремінісцентує давні легенди та міфи, за якими земля дарує людині життя і все для нього необхідне [1, с. 26, 48, 66, 188]. Поетичні рядки презентують це так: Доки доля дорогу стеле, Доки в снах я літаю ночами. Доки весни стоять за плечима. - Подаруй мені дівчину, Земле! (М. Вінграновський); Росте $з$ землі душа, пшениия $i$ спориш, Залізо й дерево, Стопчатів $і$ Париж (Д. Павличко); ...Хоч тужитиму день у день... За стовпчатівським журавлем, Що кринищю стеріг мовчазну, За Гущуанками, де чорнозем Народив мені друга й жсону... (Д. Павличко).

Другий член цієї пари - забирателька - сформований на основі релігійних уявлень про те, що тіло людини після смерті має бути повернуто землі: Знов землю відчиняють грабарі - до глини прикрої вгрібаються лопати (П. Мовчан); Я ж у дорогу прошу з собою пам'ять вашу разом з любов'ю. Буде мені із людською ніжністю тепло в землі й несамотньо у вічності (I. Жиленко); Поховали старенького діда, закопали у землю святу (В. Симоненко); Тоді ми, вряд, упевнившись на ділі, щзо Грицьь умер, отруєний в четвер, предать землі звеліли до неділі, прийнявши справу криміналітет (Л. Костенко).

Опозиція дарувальниця-забирателька також охоплює відповідно семантичні компоненти життя-смерть, изей світ-той світ.

Родючість-неродючість. 3 ознакою «дарувальниця» тісно пов' язана ознака «родючість», що актуалізує породжувальну функцію землі. Родючість оцінюється позитивно, як благо, необхідна умова життя людини: Моя земля плодюча $і$ розлога, Розумна й старша від самого Бога... (Д. Павличко); Прудка й невтомна кров Чингіза, Мов іскра грому в чорній млі, Погасла, та не від заліза, $A$ від плодючої землі! (Д. Павличко).

Негативною властивістю вважають неродючість землі, адже це пряма загроза життю людини: Удощ̧и цүю прісну землю, удощзи, заручи мені щзе долю, заручи... (П. Мовчан); Навіщуо я відкрився горам, Де кров звисає з гострих скель, Навіщуо перейнявся горем Вдовиних ялових земель? (Д. Павличко).

Краса-потворність. Як одну 3 найдавніших i найпоширеніших дихотомій, опозицію «краса-потворність» передбачає i концепт земля, ілюструючи дуальність лінгвалізованої реалії, широту світогляду народу, який не розділяє прагматичне й естетичне. Краса землі має божественне походження та вербалізується поетами як щось благородне і чисте: Cвimaє,
() А. O. Оrap, 2011. 
господи, світає... Земля у росах, як в парчі. Маріє, Діво Пресвятая, изе ти так плакала вночі? (Л. Костенко); Люди - прекрасні. Земля - мов казка. Кращзого сония ніде нема (В. Симоненко); Перед лицем прекрасної землі Не можу буть негарною, не хочу (І. Жиленко).

Потворність у структурі концепту земля має іншу природу: обличчя землі спотворює, в основному, людина. Діяльність людини спричинилася до жахливих наслідків: земля що раз більше потерпає від екологічних катастроф, вони спотворюють, отруюють їі, що в концепті земля семантизовано як асоціативна паралель «земля-екологія»: 3 рідного грунту смокче смертники коріння, згубних розщеплень частки дрібні (П. Мовчан); I світ потворив словом та мовчанням: паплюжив землю, криниці труїв... (П. Мовчан); Мені привиділось затемнення Землі: водневих бомб чорнолетючі зграї, I людство. Скорчене у попелястій млі, I хмари. Як nanip, горять у небокраї (М. Вінграновський).

Певність-непевність. До зародження у концепті земля ознаки «непевність» спричинилися релігійні віровчення, а остаточно вишліфували iii наукові дані про землю як планету, що обертається у космосі. На таку етимологізацію цієї ознаки наштовхує поезія: Показує нам море, щзо земля - Це рух окопів, линучих здаля, Це рух могил, поміж яких людина Веде свого хиткого корабля (Д. Павличко); Благослови веселу звичку жить. Під крилом крука, злим $і$ невблаганним. На цій непевній кулі під ногами (І. Жиленко); Земля - на трьох слонах - втрачає рівновагу, $i$ сиплеться труха із черепахи. І все непевно тут. А ми живем (I. Жиленко).

Другий член згаданої опозиції - певність - укорінений у структурі концепту завдяки опорним функціям землі, їі стійкості: на неї опирається людина й усе суще: I в землю надійно вростає стіл (І. Жиленко); Земля в ногах - слухняна і легка (І. Жиленко).

Окрім такого фізичного аспекту, є ще й інший, відповідно до якого земля - джерело духовної наснаги, з неї людина черпає силу й натхнення: Наливайся земними силами, Вдосталь радощів зачерпни - Над тобою тріпочуть крилами Тихі-тихі спокійні сни... (В. Симоненко); I той любов'ю повниться до світу, хто рідну землю має під собою (М. Вінграновський).

Твердість-м'якість. Поетичний дискурс другої половини ХХ століття особливо виразно вербалізує такий компонент концепту земля як «твердість». Мовні засоби його репрезентації різноманітні: ад'єктив твердий (А моє сериее - то тверда земля, То Хортиия, скатована навіки (Д. Павличко); поетизоване словосполучення земна твердь (Порідшала земна тужава твердь, міський мурашник поточив планету (В. Стус); порівняльні структури (Навкруги кам'яна безбереж $i$ земля, наче криця (Д. Павличко); прикметники, що вказують на складники землі (Дихає зрілість моя на зорі Землею крицевою $i$ цукровою (I. Драч); часом поєднуються два способи - дієслово 3 відповідним значенням та 
порівняльна конструкція (I земля поволі твердне під коліньми, наче камінь, - відрікаючись від тебе не хвилинами - роками... (П. Мовчан).

Часте апелювання поетів до ознаки «твердість» та іï семантичний вміст дають підстави вважати іiі ядерною. Її антагоніст - «м'якість»лінгвалізовано не так часто й завуальовано: Земля ця з попелу. Століття перетліли I сипали цей попіл з рукава (I. Драч); А тут щзе вітер, небо теж якесь, земля до ніг півпуда налипає (Л. Костенко).

Глибокість-мілкість. У структурі концепту земля актуалізовано ознаки, які постають як результат освоєння земних надр. Зокрема, така ознака, як «глибина»: Осліпли від захоплених очей ї̈ чаклунські сяючі полотна, ті зриви ... у те, щзо є душа, у голубий ї̈ прозір, в закохані обвали, y задух квітів, у розкішний спалах землі, щчо вся розкрилась до глибин (І. Жиленко); С люди, щуо, неначе дерева, Коріння пустили в глибінь земну (Д. Павличко); Суизільним поглядом вона [душа] за колом коло виживляла, де приховала глибина земна усіх від голоду сконалих (П. Мовчан). Протилежна ознака - мілкість - властива не земній субстанції, а водній, тому має місце перенесення «земля - вода»: Христос воскресне, бо земля глибока - мілка для убієнного пророка (І. Жиленко). У цій іпостасі земля постає ще й як «мірило справедливості». Зазначимо, що наведені рядки єдиний зафіксований приклад, де епітет мілка вжито щодо номена земля.

Тяжкість / важкість-легкість. Ословлення обох концептуальних ознак у поезії не частотне, але все ж простежується чітко та утворює контрастивну пару: Ти показуєш у землю пальцем, я ж підвівсь недавно із землі. ... Щоб ти знав, яка тяюкка земля та, У яку показуєш злегка, Щоб з могили, люта і проклята, Терном не росла твоя рука (Д. Павличко); I в чорній брамі - та важка земля, де і моя маленька крапля крові палкою хіттю передвіків захмеля їх нетерпляче зводячи в любові (І. Жиленко) та Земля в ногах - слухняна і легка (І. Жиленко); Земля Вам пером, мій дивний друже! (І. Драч); Доп'яв біди, земля йому пером (Л. Костенко). Позитивними конотаціями наділений саме другий член опозиції, хоч i апелюють до нього здебільшого в комплексі з ознакою «могила».

Молодість-старість. Опозиційні компоненти цієї пари особливі тим, що не окреслюють смислові кордони концепту, а лише ілюструють неоднозначність сприймання та розуміння поетами землі. Часом наголошувано на іiі давності через вербалізатори-епітети сива. старенька (Я чую: ридає за ними Земля, Сива, старенька мати, Одурена своӥми синами (В. Симоненко); Навшпиньках завмерла сива земля $B$ передчутті вогненноликого подвигу (I. Драч), часом, хоча й рідко, - на іiі молодості (Може бути, щзо мене не буде, Перебутній час я перебув, Але будуть світанкові губи Цілувати землю молоду (М. Вінграновський).

Як бачимо, структура концепту земля включає антонімічні ознаки, що формують бінарні протиставлення. Їх наявність засвідчує обшир, складність, різноманіття концепту та дуалізм його природи. Кожна 3
() А. О. Оrap, 2011.
$-646-$ 
опозицій розкриває певні семантичні грані концепту, унаявлює його смисл. Наведені дихотомії виконують і аксіологічну функцію, адже їхні члени можна кваліфікувати як позитивно чи негативно марковані. Ці опозиції також можна розподілити на ядерні (якщо їхні ознаки часто актуалізовані та семантично навантажені) і периферійні, хоч трапляється, що лише один компонент протиставлення ядерний (напр., твердість). Описана методика презентації опозиційних компонентів концепту земля може слугувати моделлю для аналізу інших концептів, але це вже предмет подальших лінгвістичних розвідок.

\section{Література}

1. Войтович В. Міфи та легенди давньої України / Валерій Войтович. - Тернопіль : Навчальна книга - Богдан, 2009. - 392 с.

2. Данилюк Н. О. Розвиток семантики народнопісенного слова в сучасній українській поезії / Н. О. Данилюк // Українська мова і література в школі. - 1983. - №8. - С. 36-42.

3. Кубрякова Е. С. Краткий словарь когнитивных терминов / Под общей ред. Е. С. Кубряковой. M., 1997. -245 c.

4. Лобур Н. Культ землі в українській мові / Лобур Надія // Дивослово. - 1996. - №3. - С. $22-23$.

5. Маслова В. А. Когнитивная лингвистика / В. А. Маслова. - М., 2008.-272 с.

6. Мацьків П. В. Концептосфера Бог в українському мовному просторі : [монографія] / Петро Мацьків. - Дрогобич : Коло, 2007. - 332 с.

7. Пименова М. В. Концептуальные структуры и язык: статика и динамика / Пименова М. В. // Язык и дискурс в статике и динамике: тезисы докл. Междунар. науч. конф. / ред. колл. 3. А. Харитончик, А. М. Горланов и др. - Минск : МГЛУ, 2008. - С. 110-111.

8. Слюніна О. В. Концепт земля в українській мовній картині світу: лінгвокогнітивне осмислення / О. В. Слюніна // Лінгвістика : зб. наук. праць. - Луганськ, 2009. - № 1(16). - С. 159-169.

9. Степанов Ю. С. Концепт // Ю. С. Степанов Константы : Словарь русской культуры. Опыт исследования. - М., 1997. - С. 40-76. - Режим доступу: http://philologos.narod.ru/concept/stepanov-concept.htm.

10. Франко І. Я. Влада землі в сучасному романі / І. Я.Франко // Зібрання творів : [у 50 т.]. - 1980. T.28. - C. 176-195.

11. Шуляк С. Лексична інтерпретація концепту земля у поезії Свгена Гуцала / Світлана Шуляк // Вісн. Львівськ. ун-ту. - 2004. - Вип. 34. Ч.ІІ. - С. 249-253. 